fessionals in the academic community.

2. Establish mechanisms for identifying and responding to bodies created to study issues of importance to academic libraries.

3 . Encourage and facilitate effective membership response to government and private sector activities, including appropriate legislation.

\section{Goal IV}

To promote study, research, and publication relevant to academic and research librarianship.

\section{Subgoals}

A. To promote awareness of the need for research, identify study and research topics, and encourage improvement in research skills.

B. To participate in research projects, report works in progress, and disseminate research results.

C. To support research relating to academic and research libraries.

D. To sponsor a strong publishing program that will advance the professional knowledge and understanding of academic librarians.

\section{Critical Objectives}

1. Develop and implement a research agenda for academic libraries.

2. Create appropriate mechanisms for identifying, collecting, storing, and disseminating research of interest to academic and research librarians.

3. Undertake a comprehensive review of the ACRL publications program to ensure that the objectives are being met.

\title{
External factors analysis statement
}

The first draft of this statement was prepared by the ACRL Planning Committee. It was then revised by the ACRL Strategic Planning Task Force and incorporated into their planning process, which will culminate in a written five-year plan for the Association. The statement is essentially an updating of the environmental considerations portion of the original ACRL activity model (C\&RL News, May 1982, p.164).

A. Economic Considerations.

1. The concept of information as a commodity will increasingly influence decisions relating to libraries.

2. Steady-state or declining purchase power will be available to academic/research libraries.

3. Costs of computing hardware will decline; the costs of software and telecommunications will increase.

4. Competition between libraries and other organizations, both on campus and in the for-profit sector, will increase.

5 . Libraries will be expected to increase productivity.

\section{B. Political Considerations.}

1. Information will be an increasingly important strategic factor in domestic and international markets and in world politics.

2. Conflict will escalate among government, business and academia over the ownership, value, and control of information.

3. Federal government attitude toward academic/research libraries will be increasingly laissez-faire.

4. State governments will increase efforts to centralize authority/control over tax-supported higher education, including academic libraries.

5. The distribution of computing power will di- minish the political impact of national consortia.

6. Local, state, and regional computer-based networks will continue to develop.

7. There will be continuing international pressure for bibliographical standardization.

C. Social Considerations.

1. Equality of opportunity for women and minorities will continue to be an elusive goal.

2. Illiteracy will continue to be a problem in spite of the efforts of schools, libraries, and the educational reform movement.

3. Well-organized political and religious groups will continue to mount challenges to intellectual freedom.

4. The development of massive databases may threaten individual privacy.

5. Academy-based research activity will advance slowly.

6. The demographic profile and educational needs/expectations of college students will continue to change.

7. The use of non-print and micro-based materials in research and college teaching will increase.

8 . Society will continue to press for dollar accountability.

(continued on next page)

\section{Strategic planning forum}

The ACRL Strategic Planning Task Force will be holding an open forum during the Midwinter Meeting on January 20 from 4:30 to 6:30 p.m. The forum is being held to allow ACRL members and other interested parties to respond to the first draft of the ACRL Strategic Plan, published in this issue. 
D. Technical Considerations.

I. Word processing/communication/computer technology will improve and proliferate.

2. Advances in storage technology will alter the way in which information is published and distributed.

3. Changes in technology will change the kinds of information services provided.

4. Libraries and the for-profit sector will be in competition to meet the demand for speedier delivery of information/documents.

5. Personal ownership of word processing/computing/telecommunications hardware and software will continue to increase.

6. As the use of terminals and microcomputers grows, access to information will become more decentralized.

7. Preservation methods for disintegrating library book stocks will become more effective and more widely used.

\section{E. Human Resources.}

1. The rigorous competency standards of the educational reform movement will improve the performance of both teachers and students in public schools.

2. Scholarly communication will continue in its present state of relative good health; researchers, scholarly publishers, and librarians will continue to be the major links in the process.

3. Libraries will not become less labor intensive but will require a new mix of staff and skills.

4. Libraries will remain in competition with other organizations for staff.

5 . Society will require training and the help of intermediaries to use proliferating online information sources.

6. Information management and data processing staff will be increasingly costly to hire and retain.

\section{ACRL's 1985/86 budget}

\section{Last year's performance and this year's projection.}

$\mathbf{L}$ ast year, when we presented the budget article in CむRL News (December 1984, pp. 599-606), we pointed out the program nature of the budget, and tied each budget item to a specific objective in the ACRL statement of goals and objectives. This year's budget is again based on our programs. Expenses are incurred and revenue generated in the accomplishment of ACRL's mission and goals.

The mission of the Association of College and Research Libraries (ACRL) is to foster the profession of academic librarianship. To accomplish that mission, ACRL has established four goals:

- To contribute to the total professional development of academic and research librarians.

- To improve the service capabilities of academic and research libraries.

- To promote and speak for the interests of academic and research librarianship.

- To promote study and research relevant to ac- ademic librarianship.

On pp.605-7 in this issue is a draft of the work of the Strategic Planning Task Force in revising the ACRL mission statement, goals, subgoals, and objectives. Until the process for adopting the final version of the Strategic Plan for the Association is complete, the mission statement and goals mentioned above are those driving ACRL. By this time next year, we will have moved into the new plan. In the meantime, the program activities remain tied to the present goals and objectives in the manner described in last year's budget article.

\section{Highlights of 1984/85 performance}

ACRL's fund balance again increased (by $\$ 74,298)$ to $\$ 472,193$ from the September 1984 figure of $\$ 397,895$. This increase came in the publications area, where advertising, particularly classi- 